\title{
Józef Brudziński
}

\author{
Monika Nowakowska-Zamachowska
}

Department of History of Medicine, Collegium Medicum, Jagiellonian University in Cracow

Józef Polikarp Brudziński was born in the village of Bolewo on 26 January 1874 and died in Warsaw on 18 December 1917. On graduation from the $4^{\text {th }}$ grammar school in Warsaw in 1891, Brudziński embarked on medical studies in Tartu and Moscow, where he received his medical diploma in 1897. He began his medical practice as a paediatrician under Prof. Jakubowski in the Cracow university hospital. He pursued this medical specialty in Graz under the supervision of Prof. Escherich and then in Paris with Professors: Granscher, Marfan and Hutinel. He also visited hospitals in Vienna, Zurich, Basel, Cologne and London. In 1900, he returned to Poland, where he lived and worked until his death. He pioneered modern paediatrics in Poland and in Europe, and discovered reflexes associated with meningitis which are vital in today's neurology. Brudziński also headed Poland's first modern paediatric hospitals in Łódź and Warsaw. He authored a total of 55 scientific works. In 1909, Brudziński was granted the degree of doctor of medicine (Doctor Medicinae Universae) from the Jagiellonian University without examinations. In addition to scientific work, Brudziński was actively engaged in social and political initiatives. He died prematurely of nephritis at the age of 43 , in Warsaw.

\section{Józef Brudziński - paediatrician}

Józef Brudziński organized advanced paediatric hospital care and paved the way for modern Polish paediatrics based on rigorous clinical reasoning and thorough theoretical knowledge. In 1900, began his practice in the Rev. G. P. Baudouin's Foster Care Centre at Warsaw's Infant Jesus Hospital. At the same time, he launched endeavours to build children's hospitals in Łódź and Warsaw, which became the work of his life- time. He succeeded in completing the first part of his project three years later. The Anna Maria Hospital, designed and established basically through Brudziński's efforts, was located in a poor industrial area of Łódź. Brudziński held the function of Chief Physician at the hospital. Thanks to his commitment, the hospital became one of the first supremely advanced children's hospitals in Europe and a centre of modern paediatrics. The period also saw the publication of Brudziński's most important works in paediatric gastroenterology, pulmonology and childhood infectious diseases. In his hospital, he introduced a method for treating intestinal infections in children (caused predominantly by Proteus vulgaris) with Bacterium lactis aerogenes cultures. The first reports in international medical literature claiming that simultaneous inoculation of lactic acid bacteria and Proteus vulgaris onto a plate containing a gelatin medium inhibited the growth of the latter, as well as pioneering attempts to cure diarrhoea with buttermilk, aroused Brudziński's interest in the problem of such vital importance in paediatrics. Brudziński applied his own highly effective therapeutic strategy based on giving infants orally 24-hour cultures of Bacterium lactis aerogenes suspended in sterilized whey which, containing less protein, had an important advantage over buttermilk in terms of reduced burden on the digestive system of sick children. The method, though considerably improved, has been in use until today. Brudziński described the percussion sign accompanying exudative inflammations in children and proposed a theoretical explanation for the Grocco-Rauchfuss-Hamburger sign. He introduced a strict differentiation between scarlet fever and measles, demonstrating the specificity of infectious agents causing the two diseases. He undertook studies of neurological signs associated with meningitis in children. 
Brudziński also organized the first paediatrics section operating at the Medical Association in Łódź. He was one of the founders of first Polish journal of pediatrics entitled Przeglad Pedyatryczny [Paediatric Review] and the journal's editor-in-chief in 1908-1914. It is through his efforts that separate Polish sections were established at international paediatrics congresses.

In 1913, Brudziński implemented the second part of his project. He assumed management of the other Polish advanced paediatric hospital - in Warsaw. The Karol and Maria Hospital was constructed and equipped strictly according to Brudziński's instructions. The establishment very quickly became a medical centre renowned in Europe for its pioneering efforts in paediatrics. It is during the period spent in Łódź and Warsaw that Brudziński made his momentous discoveries in neurology. Unfortunately, Brudziński's scientific career was cut short by his untimely death. Hospital departments run by Brudziński had been the academic home to some of Poland's outstanding future paediatricians, many of whom became heads of university departments, including Marta Erlich, Karol Jonscher and Władysław Szenajch, Brudziński's successor at the Karol and Maria Hospital.

\section{Józef Brudziński - neurologist}

All of Brudziński's works in neurology are devoted to cerebrospinal meningitis and describe new, previously unknown, neurological signs. His first work titled O odruchu drugostronnym na kończynach dolnych $u$ dzieci [On the contralateral reflex sign in the lower limbs in children] was published in 1908. The work describes a new neurological sign identified in a hemiplegic child. Flexion of the healthy lower extremity produces extension of the pathological extremity, i.e. contralateral asymmetrical synkinesis, while flexion of the pathological lower extremity triggers flexion of the healthy lower limb, i.e. contralateral symmetrical synkinesis. Contralateral symmetrical synkinesis was often identified in patients with tuberculous meningitis or epidemic meningitis. In his later works, Brudziński described symptoms that are widely known today as Brudziński's neck and symphyseal signs and Brudziński's cheek phenomenon. Brudziński's neck sign, the one most often used in today's clinical practice, was described in his 1909 paper entitled $O$ nowym objawie na kończynach dolnych w zapalenin opon mózgowo-rdzeniowych u dzieci [On a new sign in the lower extremities observed in children with cerebrospinal meningitis]. Brudziński, however, was not content with a mere description of neurological signs. He was vitally interested in their pathogenesis. To this aim, he performed a range of experimental studies on frogs, birds, dogs and rabbits at the Physiology Department of the Jagiellonian University under Prof. Napoleon Cybulski. Signs first reported by Brudziński, and named after him, were reported in the international medical literature and included in all highly respected handbooks on neurology from such authors as: Marfan, Oppenheim, Feera, Ibrahim and Dejerine. They also became the subject of a number of doctoral dissertations at French and English universities. They are now a vital component of neurological assessment worldwide. Even though Brudziński's name is most readily associated with neurology, it should not be forgotten that he was, above all, a distinguished paediatrician.

\section{Józef Brudziński - social activist and politician}

In mid-July 1915, following resignation of Russian authorities in the wake of the movement of the Western Front to Warsaw, Polish intellectual elites undertook activities aimed at the repolonization of Polish institutions, with a particular focus on cultural, educational and scientific institutions. A new Department of Education was established incorporating a Section of Higher School Education. A part of the Section, called the University Committee, was tasked with establishment of a Polish university in Warsaw. Brudziński, who headed the Committee, made a crucial contribution to the quick organization and opening of the University in November 1915. It comes as no surprise, then, that he was appointed the first Rector of the new school. He also took office as Head of the Department of Medical Propaedeutics, where was a lecturer for two years. In 1910, Brudziński was accepted as a full member of the Warsaw Scientific Society. In 1912-1917, he was also a member of the Society's Management Board.

Professor Brudziński's political activity is less known, but no less important. During his studies in Moscow, Brudziński was keenly involved in the activity of the Polish Association. In November 1916, he engaged actively in endeavours aimed at creation of the independent Polish Kingdom by the Central Powers. It was at this time that Józef Piłsudski turned to Brudziński as a "prominent representative of the society of the former Polish Kingdom" regarding the establishment of inde- 
pendent military authorities in Warsaw. In December 1916, he participated in negotiations held with Germany and Austria about the creation of the Provisional Council of State. Being a legalist, Brudziński was opposed to the escalation of anti-German attitudes among the society (young people in particular), which reduced his once huge popularity with students. This was one of the reason he refused to stand for another term in office as Rector of the university in 1917; instead, he assumed the position of the Vice-Rector. It was also in 1917, on 18 December, that Józef Brudziński passed away. His funeral in Skotniki drew crowds of several thousand people. The funeral speech was given by Leszek Serafinowicz, who later won fame as an illustrious poet publishing under the artistic pseudonym Jan Lechoń. The headstone features the following inscription: "He built in days of turmoil and despair. He embraced with his ardent heart the Past, Present and Future of the Nation".

Soon afterwards, a medal was minted in his honour and a commemorative plaque was erected in Warsaw. Brudziński's name was also given to one of the rooms in the Kazimierzowski Palace, the seat of the Warsaw University. Of Poland's major cities, only Łódź named a street after him (in the Doły district). Warsaw, a city for which Brudziński did so much good, has not seen fit to do so as yet.

\section{Literature references}

1. Brudziński J. O występowaniu Bac. Proteus vulgaris w stolcach niemowląt; próba leczenia przez podawanie hodowli bakteryjnych. Przeglad Lekarski 1899; 48: 651-653 oraz 49: 666-668.

2. Brudziński J. O odruchu drugostronnym na kończynach dolnych u dzieci. Przeglad Lekarski 1908; 9: 112-118.

3. Brudziński J. O nowych objawach w zapaleniu opon mózgowych u dzieci. Przeglad Pediatryczny 1909; 1: 360-368.

4. Brudziński J. Badania doświadczalne nad odruchem drugostronnym (objaw karkowy). Gazeta Lekarska 1910; 30: 1228-1235.

5. Herman E. Neurolodzy polscy. PZWL, Warszawa 1958, s. 159-165.

6. Śródka A. Uczeni polscy XIX-XX stulecia. Tom 1. Agencja Wydarenicza ARIES, Warszawa 1994, s. 213-214.

7. Kapłańska J. Zasługi Józefa Brudzińskiego na polu pediatrii. Archiwum Historii i Filozofii Medycyny oraz Historii Nauk Przyrodniczych 1948; 19: 61-106. 